\title{
Identity formation: An auto-ethnography of Indonesian student becomes a legitimate speaker and teacher of English
}

\author{
Rina Febrina Sarie ${ }^{1}$, Bambang Widi Pratolo², Eko Purwanti ${ }^{3}$ \\ ${ }^{1}$ Faculty of Education, Monash University, Australia \\ ${ }^{2}$ English Education Department, Universitas Ahmad Dahlan, Indonesia \\ ${ }^{3}$ English Education Department, Universitas Muhammadiyah Yogyakarta, Indonesia
}

\begin{tabular}{l} 
Article Info \\
\hline Article history: \\
Received Nov 25, 2019 \\
Revised Apr 19, 2020 \\
Accepted Jul 16, 2020 \\
\hline
\end{tabular}

\section{Keywords:}

Identity

Legitimate speaker and teacher

Non-native English speaker

teachers

TESOL

\begin{abstract}
Several studies have investigated how the TESOL program influenced the construction of Non-Native English Speaker Teachers' identities, yet few literature concerns about the negotiation of NNESTs' identity as legitimate speakers and teachers of English. This paper was an auto-ethnographic investigation of my personal experience as one of international students in the TESOL program at an Australian university. Drawing on Norton's theory of language and identity, this study examined a complex process of my identity formation as a legitimate speaker and teacher of English after studying one of a critical pedagogical unit 'Language, Culture, and Curriculum'. The findings revealed that the TESOL program enabled me to discover and explore another part of myself as a legitimate speaker and teacher of English through linguistic constructs and rich knowledge given in that unit. It also supported that a critical pedagogical unit could empower international students to form their identities as confident and professional English teachers back to their countries.
\end{abstract}

This is an open access article under the CC BY-SA license.

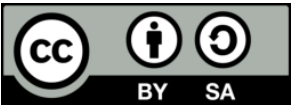

\section{Corresponding Author:}

Bambang Widi Pratolo,

English Education Department,

Universitas Ahmad Dahlan,

Jl. Pramuka 42, Sidikan, Yogyakarta, Indonesia.

Email: bambang.pratolo@pbi.uad.ac.id

\section{INTRODUCTION}

In the field of English language teaching, particularly in Teaching English to Speaker of Other Language (TESOL) area, the investigation of who owns English internationally has been critically examined by researchers. Recent literature in this field which concern with this relevant issue can be identified from different perspectives. In the perspective of linguistic, the experts have critically examined the construct 'native-speakerism' paradigm and its misconception and argued that both native and non-native speakers have authority to own English as an international language [1-3]. From the sociological point of view, the concept of legitimate speakers from [4] has become 'a darling' used by researchers to demonstrate how language learners and Non-Native English speaker teachers can be legitimate speakers of English [5, 6]. From the cultural perspective, the postcolonial concepts of the self refer to the colonizer (native English speaker) and the other means the colonized (non-native English speaker) has been criticized and now it reveals that the image of the other is simply the generalization and imagination of the self towards the other [7-10]. Not only challenge and criticizes the self in regard to their assumption and perception of others but also negotiate and empower the other (non-native speakers) as the owner of English [10]. 
In relation with the impact of TESOL program on the construction of NNESTs' identities, several studies concern with the situations and condition in which language learners need to become the legitimate speaker of English [11]. Others also are interested in the negotiation of NNESTs' identity as legitimate speakers and teachers of English [12-15]. The important study conducted by [16] related to shaping international students as legitimate speakers and teachers after they took TESOL program, reveals that the role of TESOL education programs play significantly in supporting the imagination of new teacher identities through alternative discourse $[15,16]$ for instance, "native speaker fallacy" by [17] from the unit offered may help these international students to legitimize themselves as speakers and teachers of English.

Reading all literature related to NNESTs' identity formation and reflecting my personal experience as one of international students in TESOL programs at one Australian university. I began to wonder how I am able to form and construct my own identity as a legitimate speaker and legitimate teacher of English through the TESOL program I have been attending. In addition, I want to examine to what extent all materials and resources given by my program help me to establish my legitimacy. Therefore, this paper aims to explore the complex processes of my identity formation as a legitimate speaker and teacher during the TESOL program.

\section{Identity in language learning}

This study adopted Norton [18] notions regarding identity as the theoretical framework to examine the identity of myself. The three characteristics of identity such as: a) identity is diverse: This diversity means in this context that identity is "produced in a difference of social sites, which are structured by relations of power in which the person has different subject position as teacher, child, manager, and critic." Through the diverse positions from where and which language learners can participate in social life, thus identity is theorized as multiple and diverse; b) identity as a site of struggle: is a logical continuation of the position that identity is complex and contradictory." People may experience different identities through their participation in social context and may take up among the identities within them. Noticing the identity as a sit of struggle, thus, researchers have investigated and exemplified on how language learners struggle to construct their own identities through learning English [10]; c) identity changes overtime: Norton emphasizes that the change of identity happens because people may experience either these two conditions or situations.

\section{How can individual become a legitimate English speaker?}

As stated by Norton [6] that with the purpose of becoming legitimate speaker of English, the learners may need to develop "awareness of the right to speak." Furthermore, while the language learners are positioned in specific way within a discourse given, they may oppose the subject position or start to counter the discourse by positioning themselves more powerful than another marginalized subject position [18]. So that's why in this context, the language learners can take a part to speak English inside the class and also in social interaction. According to McKay and Wong [5], the legitimate speaker requisites to be acknowledged as "having the right to speak, and having value assigned to what is spoken."

As in education context, to be heard when speaking and without anxiety is quite challenges for language learners who learn foreign language. Sometimes, when students speak English with different accent or in a way that they are heard as non-standard, there might be such a judgement to this speaker. In some cases, there may be a negative evaluation not just about the accent but also speakers' social identity. Thus, McKay and Wong [5] emphasises that being heard and audible to others as well as being acknowledged as a speaker of English may determine the extent to which language learners can participate in their social interactions and negotiations within educational institutions. Hence, "Audibility" in this sense is defined as the way or action speakers are heard as well as understood by other legitimate English users.

Another condition to be considered as a legitimate speaker of English is by moving forward from a "birthright paradigm" to an "appropriate model" [19]. Birthright paradigm refers to those speakers whose mother tongue is English will be always legitimately regarded as the owner of English, while appropriation model in this sense emphasises is concern with the successful appropriation of English as an additional language. In this regards, multilingual speakers need to be encouraged to see the language ownership not as a concept but put attention more on a linguistic repertoire that can be expanded [19].

\section{Identity formation of NNESTs as legitimate speakers and teachers}

As it was pointed out in the introduction to this study, several studies have investigated the issue of students and NNESTs' legitimacy. Study conducted by Brutt-Griffler and Samimy [12] study reveal that the process of empowering international postgraduate students in TESOL as legitimate teachers was "neither simple nor linear." They were able to analyse the causes of their powerlessness, and created a new sense of agency to form their identity with professional legitimacy. In addition, Golombek and Jordan [13] in their study reflecting on a critical pedagogy of teaching English pronunciation, have investigated pre-service 
teachers in Taiwan looked at themselves as legitimate teachers of English especially teachers of English pronunciation. The study presented that the pre-service teachers had conflicted and multiple identities as legitimate teachers. They were able to imagine themselves through linguistic resources from reading provided by the course.

\section{RESEARCH METHOD}

In this study, I (the first author) used auto ethnography to be "highly personalized account that draws upon the experience of author for the purposes of extending sociological understanding" [3]. In relation with this, Brodkey (1996 as cited in [10]) creates her metaphor of auto ethnography as a method in which it is based on data collected from "interview with the self" and also memories which are treated as "data" are discussed and analysed. I came to this auto ethnography as I wanted to answer the questions on how I form my identity as a legitimate speaker and teacher of English during my study in TESOL program. Thus, in the light of discussion, I now write my auto ethnography.

\section{a. Sarie as a speaker of English}

I will start my story by telling my experience as a learner of English. I started to learn English when I was nine years old in one of English language course in Palembang. I might say that I started earlier than my friends at elementary school as English became a compulsory subject taught in fourth grade. I remembered for the first time I pronounced the words in English and my teacher directly gave feedback which demotivated me to speak English at the time. Remembering my memories when I failed in English exam and it made me frustrated. That's why I thought I was not legitimate to be English user. I was also not confident of my English competency.

When I was junior high school, my motivation to learn English increased as I had a chance to join such an English competition in my school. I was representative from my class to join speech competition in an annual English speech contest held by school. Eventually, I became the first winner and it boosted my confidence to always practice speaking English. Yet, it changed when I came to bachelor degree and studied English language teaching program for about 4 years in one of private university in Jakarta. English is used as medium of instruction in my university. As this university cooperated with one of American college, then several university staffs also coming from US as well. I realized that I got much exposure to American accent then my belief at the time was speaking using American English as standard of being a legitimate speaker of English.

My next life episode was encountering with English when I came to Australia to continue my postgraduate at an Australian university. My belief that I was not a legitimate speaker of English was strengthened when I was in my first semester and during discussion, the local students were dominating classroom discussion. Then I did not feel confident. Yet, on the other side, I tried to join one of program namely Let's Chat which gave me the opportunity to speak as well. Then, my perception changes now as I am in $3^{\text {rd }}$ semester already and I found other units I selected which more focus on my field, TESOL such as pedagogy in TESOL, bilingualism, even this unit language culture and curriculum. They opened up my mind. As I also read a very good book from [10] entitled Teaching English as an International Language: Identity, Resistance, and Negotiation which she is as the author and other scholars argue that English is owned not only by native speakers but also non-native speakers and learn it because it is an international language. Thus, it empowers me to be a legitimate speaker of English this present till future.

\section{b. Sarie as a teacher of English}

After graduated from a bachelor degree in English language teaching program, I had a chance to teach English in one of private school in my hometown, Palembang. My experience as an English teacher actually began when we had a school experience program in university, at the time, we had opportunities to teach English in several schools starting my first semester until my last semester. During that SEP, I was assigned to private and international based school. At the time, in my school, we are supervised by native English speaking teachers and it means we would cooperate together. At the very beginning I was feeling inferior as an English teacher especially when we had a parents-teacher conference and I could see that the parents tend to more admire the NESTs rather than any NNESTs. Until I come here and studying at Monash, it enlightened me in a way I realized that NNESTs like me are not necessarily inferior to NESTs. Any speakers of English have the potential to become ideal teachers of English regardless of linguistic and racial backgrounds. Such arguments empowered my own position as a legitimate teacher of English. 


\section{c. Overview of TESOL program}

TESOL program at one Australian University offers a critical pedagogical unit called EDF5640 Language, Culture and Curriculum. This unit explores on how issues around language, culture identity plays out in language curriculum in particular context or even across the globe. By studying this unit, students are expected to develop an understanding of language as cultural, social, and political practice, critically reflect on how this understanding is relevant as educator through their identities and experiences. Accordingly, this unit also equips students with knowledge about particular issues related native-speakerism fallacy, identity formation, the notion of self and other. Within this unit, students are able to use the theory of interrelationship between language and culture by [20], language and representation by [21] which lead students to the postcolonial concept of the Self and the Other, the notion of identity in language learning which emerging the issue of social identity, investment, and language learning by [6]. The issue of English as an international language is challenged, the dichotomy of native speaker and non-native speaker in language teaching is also being debated, and the urgency of critical pedagogy in English language teaching is discussed. During the whole of this unit, students also discuss some prominent author such as [10, 22-25] and other experts in related to this issue.

What is distinguished this unit is that there is critical discussion toward the issue of language learning and teaching through the angel of cultural, social, and political contexts. Aside from that, a postructuralist view of identity is also introduced as a theoretical lens to apply important issues in ELT. According to postructuralist, identity is dynamic, fragmented, multiple and contradictory [21, 26, 27]. Not only that, the reading provided in this unit also from the perspective of both Western and non-Western scholars. Hence, by studying this unit, postgraduate students are hoped to speak out in related to the issues that have been mentioned above as well as explore their own identity and legitimate status as speaker of English with the power and capability they have.

\section{RESULTS AND DISCUSSION}

\subsection{Identity as changing overtime}

In this section, two main points were discussed, firstly, how my knowledge of the unit EDF5640, Language, Culture, and Curriculum as the tool of change, secondly, imagining another instructional practices of teaching.

\subsubsection{Knowledge of EDF5640 as tool of change}

\section{a. Becoming a legitimate speaker of English}

To establish how I changed my attitudes towards my status as a legitimate speaker of English, I began to analyse on how I employed several linguistic construct and issues brought up in the unit for example, "an awareness of the right to speak" [6], multilingual speaker, issue about accent, and the ownership of English. Firstly, I noted on how I could claim my right to speak English. It happened when I joined one of program for international students which called, "Let's Chat". I got the chance to raise my voice through this program. Sometimes in the end of the class, I was still talking with the tutors who are local students at this Australian university. I socialised with those local friends who wanted to know more about Indonesian culture and I thought this made me a legitimate speaker in the perspective of the mainstream hearers.

In relation to the linguistic construct, I found that sometimes I focused on the accent to label the change in a way I see myself, to being equal to all English native speakers. I used to attempt to always practice American accent in order to look such a 'cool' and become legitimate speaker of English. However, everything changed as I was attending ED5640 and I realized that there is no need to be an American native like because English was actually not only belong to or the property of British or American yet it is a global language.

\section{b. Becoming a legitimate teacher of English}

At the very beginning, I did not realize that the unit Language, Culture, and Curriculum would give me such an impact on my identity construction. Yet, it helped me change my perspective and attitudes toward my status as teacher of English. My realisation was all based on the linguistic construct what so called, the native speaker fallacy and also related knowledge of dichotomy between NESTs and NNESTs. Based on my experience during the time I worked with NESTs in one of private and international based school in my hometown, sometimes I felt inferior to them in terms of English competences. Something made me sad at the time, when we had parents-teacher conference in the end of semester; I could see how parents really admire these native English teachers. In fact, sometimes in terms of preparedness, local teacher might do better than NESTs. Consequently, as argued by Philipson [17] that native teachers are not necessarily best 
teachers. Even though, they are competent in the language but it does not guarantee they always perform well in the classroom.

\subsubsection{Imagining another instructional practice of teaching}

Based on my personal experience, I could picture myself on how I would teach English as I returned home which would help me to become legitimate teachers of English. First, by gaining experiences living in Australia, I could teach English and connect it to the culture. In this opportunity, I would use cultural materials like Western movies or music in order to make students understand English subconsciously. Another strategy that might be used for instance by comparing and finding similarity between the target language and mother tongue as well as teaching them to interact cross culturally.

As I experienced different teaching method from the TESOL program, I found Communicative Language Teaching (CLT) is still applicable and beneficial for my teaching context. As CLT is proved as an effective approach that can make students communicate and engage actively in the classroom by implementing role play, games, task-based communication which also emphasis on group work [28]. Therefore, I concerned with this teaching method I could apply as a legitimate teacher of English in my own language teaching context.

According to Norton [11], the change of identity may happened when a person imagine his or herself in a new community with new future visions and this is considered as "imagined community" and "imagined identity." In this study, it can be identified that I was able to imagine how I would teach English when I return home. In this sense, the "imagined community" refers to EFL classroom setting and context where teaching English can be using both target and local culture, comparing cultural difference, applying CLT to my EFL context and empowering students as legitimate speakers or learners of English [29-31]. Then, the "imagined identity" would be my new identity as a legitimate teacher of English with any creative above ways of teaching English. Apparently, this imagination is an effective tool to show how constructive and transformative my identity is likewise the support of linguistic resources from unit 'Language, Culture, and Curriculum'.

\subsection{Implications for TESOL teachers}

Having known that this TESOL program helped me in forming my identity, this could be better to offer new directions for TESOL program in general and unit EDF5640 in particular. Several recommendations and suggestions might help international students in this TESOL program to represent themselves through participation inside or outside classroom. Firstly, this unit can encourage students to develop their own expertise or strengths in a way that can build their legitimacy, for example strengthening aspects of their teacher identities similar to their experience in learning English, their knowledge of appropriate pedagogy for their own teaching setting and the cultural and linguistic background which they share with the students. By acknowledging international students in this TESOL course to focus on those factors which build their legitimacy up, thus the TESOL teachers or instructors can propose them new directions for imagining their identities that challenge the stereotypes that will face.

In addition, the recommendation for TESOL program can be proppsed by providing support to the imagination of teacher identities through particular discourses. These alternative discourses are "awareness of the right to speak" by [6], native speaker fallacy [17, 32-34], bilingual and multilingual speaker [23] from the unit Language, Culture, and Curriculum which offered by faculty of education, especially for TESOL studies. These discourses may help international students to legitimize themselves as speakers and teachers of English at the same time challenge the common beliefs about Non-Native English Speaker Teachers. In a wider context, to help build confidence within EFL teacher's identity, sustainable participation and engagement in a professional development such as lesson study is considerably beneficial [35].

\section{CONCLUSION}

To sum up, this study had explored my personal experiences through studying EDF 5640 in TESOL program. I had discovered and explored another part of myself as a legitimate speaker and teacher of English through linguistic constructs and rich knowledge given in this unit. This study also supported that a critical pedagogical unit like this in a postgraduate level enabled international students to form their identities, which made them be more confident as native English speaker teachers back to their country. As a closing statement, the journey of identity formation as legitimate speaker or teacher was actually never ending and still ongoing. Then, this unit 'language, culture, and curriculum' had given such an impact on how we see ourselves and make a connection to the social and cultural world in learning and teaching English. It opened up my mind and changed my perspective as non-native English speaker teachers that we were legitimate to be speaker and teacher of English. 


\section{ACKNOWLEDGEMENTS}

A general, less detailed version of this paper was presented at one of the parallel sessions at the 5 th UAD TEFL International Conference (UTIC) 2019, held from 3 to 4 September 2019, at The Eastparc Hotel, Yogyakarta, Indonesia. Thanks to UTIC for giving permission to publish it as a full-length paper in a journal.

\section{REFERENCES}

[1] A. Davies, The Native Speaker Myth and Reality. Clevedon; Buffalo: Multilingual Matters, 2003.

[2] C. Higgins, "'Ownership" of English in the outer circle: An alternative to the NS - NNS dichotomy," TESOL Quarterly, vol. 37, no. 4, pp 615-644, 2003.

[3] A. C. Sparkes, "Autoethnography and narratives of self: Reflections on criteria in action," Sociology of Sport Journal, vol. 17, no. 1, pp. 21-43, 2000.

[4] P. Bourdieu and J. B. Thompson, Language and symbolic power. Harvard University Press, 1991.

[5] S. McKay, et al., "Multiple discourses, multiple identities: Investment and agency in second-language learning among Chinese adolescent immigrant students," Harvard Educational Review, vol. 66, no. 3, pp. 577-608, 1996.

[6] B. Norton, "Social identity, investment and language learning," TESOL Quarterly, vol. 29, no. 1, pp. 9-31, 1995.

[7] A. Holliday, The Struggle to Teach English as an International Language. Oxford University Press, 2005.

[8] A. Pennycook, English and the Discourses of Colonialism. London; New York: Routledge, 1998.

[9] L. H. Phan, "University classrooms in Vietnam: Contesting the stereotypes," ELT J., vol. 58, no. 1, pp. 50-57, 2004.

[10] L. H. Phan, Teaching English as an International Language: Identity, Resistance and Negotiation. Clevedon: Multilingual Matters, 2008.

[11] B. Norton, "Non-participation, imagined communities and the language classroom," Learner contributions to language learning: New directions in research, vol. 6, no. 2, pp. 159-171, 2001.

[12] J. Brutt-Griffler and K. K. Samimy, "Revisiting the colonial in the post colonial: Critical praxis for NonnativeEnglish-Speaking teachers in a TESOL Program," TESOL Quarterly, vol. 33, no. 3, pp. 413-431, 1999.

[13] P. Golombek and S.R. Jordan, "Becoming "black lambs" not "parrots": A poststructuralist orientation to intelligibility and identity," TESOL Quarterly, vol. 39, no. 3, pp. 513-533, 2005.

[14] J. Miller, Audible Difference: ESL and Social Identity in Schools. Clevedon: Multilingual Matters, 2003.

[15] A. Pavlenko, "“I never knew I was a bilingual": Re-imagining teacher identities in TESOL," Journal of Language, Identity and Education, vol. 2, no. 4, pp. 251-268. 2003.

[16] P. T. T. Xuan, "Speaking out or keeping silent: International students' identity as legitimate speakers and teachers of English," TESOL in Context, vol. 24, no. 1, pp. 7-27. 2004.

[17] R. Philipson, Linguistic Imperialism. New York: Oxford University Press, 1992.

[18] B. Norton, Identity and language learning: Gender, ethnicity and educational change. Editorial Dunken, 2000.

[19] A. Parmegiani, "Reconceptualizing language ownership. A case study of language practices and attitudes among students at the University of KwaZulu-Natal," Language Learning Journal, vol. 38, no. 3, pp. 359-378, 2010.

[20] C. Kramsch, Language and culture. Oxford University Press, 1998.

[21] S. Hall, "Introduction", In Hall (Ed.). Representation, cultural representations and signifying practices, pp. 1-11. London, U.K: Sage Publications, 1997.

[22] A. Canagarajah, Resisting Linguistic Imperialism in English Teaching. Oxford: Oxford University Press, 1999.

[23] V. Cook, "Going beyond the native speaker in language teaching," TESOL Quarterly, vol. 33, no. 2, pp. 185-209, 1999.

[24] N. Fairclough, Language and Power. London: Longman, 1989.

[25] R. Lippi-Green, English with an Accent: Language, Ideology, and Discrimination in the United States. London; New York: Routledge, 1997.

[26] S. Hall, "Introduction: Who needs 'identity'?" In S. Hall \& P. D. Gay (Eds.), Questions of Cultural Identity, pp. 1-17. London: Sage Publication, 1996.

[27] C. Weedon, Feminist Practice and Poststructuralist Theory (2nd ed). Oxford: Blackwell Publication, 1997.

[28] J. C. Richards and T. S. Rodgers, Approaches and Methods in Language Teaching. Cambridge: Cambridge University Press, 2001.

[29] J. Miller, "Identity construction in teacher education," In Hua, Z., Seedhouse, P., Wei, L., \& Cook, V. (Eds.), Language learning and teaching as social inter-action, pp. 148-162. London: Palgrave Macmillan, 2007.

[30] P. C. Liao, "Taiwan-Educated Teachers of English: Their Linguistic Capital, Agency, and Perspectives on Their Identities as Legitimate English Teachers," Taiwan Journal of TESOL, vol. 14, no, 2, pp. 5-35, 2017.

[31] B. Norton and A. Pavlenko, Imagined communities, identity, and English language learning in a multilingual world. Second Handbook of English Language Teaching, 2019.

[32] A. Tsui, "Complexities of Identity Formation: A Narrative Inquiry of an EFL Teacher," TESOL Quarterly, vol. 41, no. 4, pp. 657-680, 2007.

[33] Z. Tajeddin and A. Adeh, "Native and Nonnative English Teachers' Perceptions of Their Professional Identity: Convergent or Divergent?" Iranian Journal of Language Teaching Research, vol. 4, no. 3, pp. 37-54, 2016.

[34] P. Medgyes and T. Kiss, "Native Speaker Teacher," Quality in TESOL and Teacher Education: From a Results Culture towards a Quality Culture. New York: Routledge, 2019.

[35] E. Purwanti and E. D. Hatmanto, "Understanding EFL Teachers' Beliefs about Lesson Study and Their Knowledge Development Viewed from Social Cultural Theory of Vygotsky," English Language Teaching Educational Journal, vol. 2, no. 2, pp. 50-61, 2019. 